http://journals.ums.ac.id/index.php/ijolae

\title{
Students' Responses Leveling in Solving Mathematical Problem Based on SOLO Ta- xonomy Viewed from Multiple Intelligences
}

\author{
Amalia Silwana $^{1}$, Subanji ${ }^{2}$, Muhamtsakree Manyunu ${ }^{3}$, ArifahAdlina Rashahan ${ }^{4}$ \\ ${ }^{1,2}$ Faculty of Mathematics and Natural Science, Universitas Negeri Malang, Indonesia \\ ${ }^{3}$ Faculty of Education, Fathoni University, Thailand \\ ${ }^{4}$ Fakulti Sains and Mathematic, Universiti Pendidikan Sultan Idris, Malaysia
}

DOI: 10.23917/ijolae.v3i1.10528

Received: March 11 ${ }^{\text {th }}, 2020$. Revised: April $7^{\text {th }}, 2020$. Accepted: April $9^{\text {th }}, 2020$

Available Online: April $20^{\text {th }}, 2020$. Published Regularly: January $1^{\text {st }}, 2021$

\begin{abstract}
This research aimed to determine the level of student response with logical-mathematical, verbal-linguistic, and visual-spatial intelligence tendency in solving mathematical problems of linear programming material based on SOLO taxonomy. The level of students' responses as the output in this research is expected to be used as a reference by mathematics teachers to determine the appropriate learning methods and strategies in accordance with the tendency of students' multiple intelligence types. It can be useful in realizing the effectiveness of mathematics learning about what needs to improved and emphasized in learning so that all students can achieve optimal responses in solving mathematical problem and can develop their multiple intelligences. This research is descriptive qualitative research with six students in the $11^{\text {th }}$ Grade of SMAN 1 Gondanglegi as research subjects: two students with logical-mathematical intelligence tendency, two students with verbal-linguistic intelligence tendency, and two students with visual-spatial intelligence tendency. Data collection was done by providing multiple intelligence classification tests, linear programming problem tests, and interviews. The result of the research showed the students' response level in solving the mathematical problem of linear programming material based on SOLO taxonomy is that students with logicalmathematical intelligence tendency reached extended abstract response level, students with verbal-linguistic intelligence tendency reached multi-structural response level, and students with visual-spatial intelligence tendency reached multi-structural and relational response level.
\end{abstract}

Keywords: mathematical problem, multiple intelligences, response leveling, SOLO taxonomy

Corresponding Author:

Amalia Silwana, Mathematics and Natural Science Faculty of Universitas Negeri Malang, Indonesia

Email: amaliasilwana@gmail.com

\section{Introduction}

The rank of Indonesia's Human Resource Competitiveness is in the $87^{\text {th }}$ out of 157 countries (Sugiarto, 2019). To improve the competitiveness of Indonesian human resources, national development is more directed to improve the quality of education. Mathematics as one of the fields of study taught from primary to secondary level education is an important part of the attempt to improve the quality of education (Novitasari, 2016). The purpose of Mathematics at school is not only understanding the concepts by students but also applying the concepts learned to solve problems in their lives. Duncker (1945) explained that problems arise when a person has a goal but does not know how to achieve his goal. When someone cannot switch from a given situation to the desired situation only by action, then the other way is through the 
process of thinking. Furthermore, Mathematics is identical to solving problems and the main purpose of learning Mathematics is to develop students' abilities in solving various mathematical problems because someone who can solve problems in daily life and at work will make a big profit (Bhat, 2014). So by studying mathematics, students are trained in solving various problems in daily life especially mathematical problems in society, so that they can prepare their lives in the future as the next generation of the nation.

Also, problem-solving is beneficial for teachers. Through the process of solving mathematical problems by students, teachers can find out the responses of each student as an effort to develop students' mathematical thinking processes (Ekawati et al., 2013). This is because when students are faced with problems, students will show their responses to the problems. Therefore, to find out the level of student response, tests can be used.

Then, the researcher conducted a preliminary study in SMAN 1 Gondanglegi. The reason for choosing SMAN 1 Gondanglegi as a place to conduct the research is because it is based on the results of observation done by the researchers. The researchers found that the problem at the school is that many students get grades below the minimum completeness grades criteria in the linear program material which causes them take the remedial test several times.

According to a preliminary test at SMAN 1 Gondanglegi, students' responses were obtained from their answers to linear programming problem-solving tests. From the twenty students who were given the test, eight students answered by giving appropriate conclusions and making generalizations to other situations or applying them to other situations. While other students made mistakes at the process skills stage with the various location of errors. Some mistakes made by students are shown in the following figures below.

$$
\begin{aligned}
& x+y \leq 40 \\
& 300 x+100 y \leqslant 9000 \\
& \text { fungsi pemetaan }=125.000 .000 x+75.000 .000 y
\end{aligned}
$$

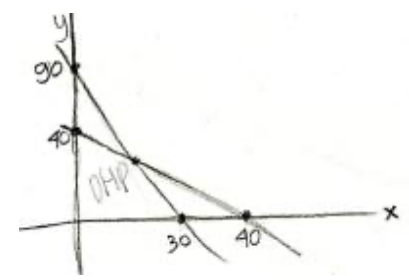

Figure 1. Answer of Student A on Preliminary Test

$f(x, y)=250.000 .000 x+350.000 .000 y$
\begin{tabular}{c|c|c}
$(30,00)$ & 0 & 10.000 .000 .000 \\
\hline$(30.0)$ & 7.500 .000 .000 & 0 \\
\hline 25.15$)$ & 6.250 .000 .000 & 5250.000 .000
\end{tabular}

Figure 2. Answer of Student B on Preliminary Test

The mistake of student A shown in Figure 1 is the student $A$ does not write all the constraints given by the problem so that the graph is incorrect. While the mistake of student $\mathrm{B}$ shown in Figure 2 is unable to determine objective function of the problem cor- rectly so that it causes an error in determining the optimum value of the problem.

Based on this, it can be seen that students show different responses in solving mathematical problems. Therefore, the teacher is expected to know the level of student 
response to detecting the location of students' lack or misunderstanding related to learning material. So, teachers can make improvements and set appropriate learning strategies as the efforts to increase students' response levels efficiently and on target. The level of students' responses, when faced with mathematical problems, can be measured by using SOLO Taxonomy. SOLO Taxonomy includes five levels of response, namely prestructural, uni structural, multi-structural, relational, and extended abstract (Wardani et al., 2017). The SOLO taxonomy was chosen to determine the level of students' responses in this research because it provides an effective and systematic way to describe students' performance to understand academic assignments given. As stated by Kuswana (2014) that the purpose of the SOLO taxonomy is to provide a systematic step describing how students perform when they grow in structural complexity when facing various tasks. Also, based on the explanation of Hasan (2017), the SOLO taxonomy has also been widely applied in various disciplines, especially in the field of Mathematics.

In responding to a problem, students process according to the intelligence capacity they have. The way students solve problems can be proven in students facing problems (Gardner, 2011). Gardner examines the diversity of human intelligence called multiple intelligences. Gardner (1999) stated that there are eight types of multiple intelligences, namely logical-mathematical intelligence, verbal-linguistic intelligence, visual-spatial intelligence, musical intelligence, kinesthetic intelligence, interpersonal intelligence, intrapersonal intelligence, and naturalist intelligence. And he suggested the ninth intelligence, namely existentialist intelligence (Allan \& Shearer, 2012).

Concerning solving mathematical problems, students with logica mathematical intelligence tendency have superiority in their ability to do mathematical calculations, students with verbal-linguistic intelligence tendency have superiority related to their ability to translate written problems, while students with visual spatial intelligence tendency have superiority in their ability to visualize the problems (Zulfairanatama \& Hadi, 2013). Then Nugroho, et al. (2013) explained that the process of solving mathematical problems requires high understanding, analysis, calculation, and imagination so that logical-mathematical, verballinguistic, and visual-spatial intelligence affect the process of solving mathematical problems. Since these three bits of intelligence have contributed to solving mathematical problems, so the intelligence used as a review in this research are logical-mathematical, verbal-linguistic, and visual-spatial intelligence.

Futhermore, some recent studies discuss about multiple intelligences, especially regarding multiple intelligences in mathematics learning. The research done by Sulaiman et al. (2010) examined teaching strategies based on multiple intelligences theory among science and mathematics secondary school teachers. Rahbarnia et al. (2014) also examined the relation between multiple intelligences and mathematical problem solving based on the revised version of Bloom taxonomy.

Considering some recent researches and the multiple intelligence approaches which have also begun to be widely applied in Indonesia (Ilyas, 2019), the researcher decided to discuss about multiple intelligences in this research. Then through the relation between intelligence and students' responses, the researcher intends to examine the extent of students' responses with logical mathematical intelligence, verbal-linguistic intelligence, and spatial-visual intelligence tendency 
when faced with mathematical problems based on SOLO taxonomy.

Furthermore, the research by Hasan (2017) examined students' responses in completing assignments based on the SOLO taxonomy viewed from students' ability levels. The other than that, the research by Salistiyani et al. (2016) also examined the students' responses level in solving geometry problems based on the SOLO taxonomy viewed from the metacognition level. No research describes the students' response level in solving mathematical problems viewed from multiple intelligences, especially students with logical-mathematical, verballinguistic, and visual-spatial intelligence tendencies.

In this research, the researcher used a linear programming problem. Linear programming is a method used to solve the problem of optimization (maximizing or minimizing) of an objective function with certain constraints in the form of equations or linear inequalities so that the goal of linear programming problems is to obtain an optimal solution (Mishra \& Ram, 2018). Based on the description, this research aimed to determine the level of student response with logical-mathematical, verbal-linguistic, and visual-spatial intelligence tendency in solving mathematical problems of linear programming material based on SOLO taxonomy.

\section{Method}

This is article using descriptive qualitative research. The research was conducted in SMAN 1 Gondanglegi at J1. Raya Ketawang No. 02 Gondanglegi. The research subjects were six students of Grade XI of Natural Science 1 Department at SMAN 1 Gondanglegi on odd semester 2019/2020. The six students consist of two students with logicalmathematical intelligence tendency, two students with verbal-linguistic intelligence ten- dency, and two students with visual-spatial intelligence tendency. The method of selecting subjects in this research is a purposive sampling (sample objectives). Criteria established as consideration in the process of selecting research subjects are (1) subjects are in the superior class of the Natural Sciences program, (2) subjects have tendencies to logical-mathematical, verbal-linguistics, or visual-spatial intelligences, and (3) subjects have good oral and written communication skills.

Data collection procedures in this research were carried out by providing multiple intelligences classification test sheets, linear programming problem-solving test sheets, and interviews. At the stage of research implementation, students of Grade XI of Natural Science 1 Department were given multiple intelligences classification tests first. The results of the multiple intelligences classification tests are analyzed by the researcher so that the researcher obtained the students who have logical-mathematical, verbal-linguistic, and visual-spatial intelligence tendencies. Furthermore, students with logical mathematical, verbal-linguistic, and visual-spatial intelligence tendencies were given linear programming problem-solving tests. Then, students with good communication skills were chosen, namely two students representing logical-mathematical intelligence tendency, two students representing verballinguistic intelligence tendency, and two students representing visual-spatial intelligence tendency as the research subjects. Besides, the research subjects were interviewed by the researcher on how to solve the linear programming problems that had been carried out by them. The results of linear programming problem-solving tests and interviews were used to analyze, identify, and classify students' responses in solving mathematical problems of linear programming material 
based on the SOLO taxonomy. Data analysis used Miles et al. (2014), which is an analysis model with three stages: (1) data condensation; (2) data display; and (3) conclusion drawing/ verification.

The data verification process in this research uses data triangulation. Triangulation techniques used in this research are source triangulation and method triangulation. Source triangulation is done by comparing the results of students work in the answer sheets and the results of interviews. Method triangulation is done by taking several subjects for one category.

\section{Result and Discussion}

Multiple intelligences tests are given to students in classes that have been determined. The results of the multiple intelligences tests of 25 students are shown in the following Figure 3.

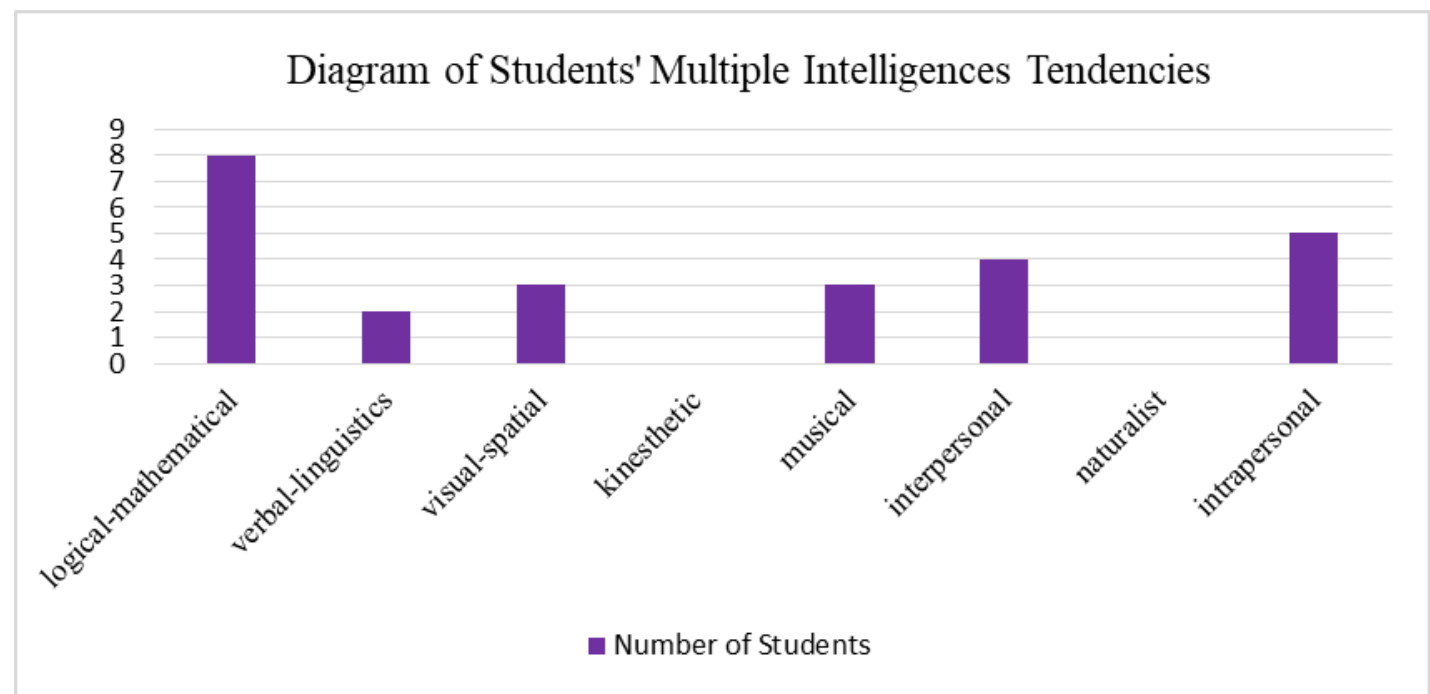

Figure 3. Diagram of Students' Multiple Intelligences Tendencies

From the multiple intelligences test results, 13 students with logical-mathematical intelligence, verbal-linguistic, and visualspatial tendencies will be given linear programming tests. Afterwards, students with good communication skills were chosen, namely two students with logicalmathematical intelligence tendency, two students with verbal-linguistics intelligence tendency, and two students with visualspatial intelligence tendency. Based on the answers given by students to the linear pro- gramming problem, students' responses can be leveled with level based on the SOLO taxonomy.

\section{Students' Responses Leveling with Logical-Mathematical Intelligence Tendency}

Students with logical-mathematical intelligence tendencies are labeled by SM 1 and SM 2. The answer of SM 1 is shown in Figure 4, and the answer of SM 2 is shown in Figure 5. 


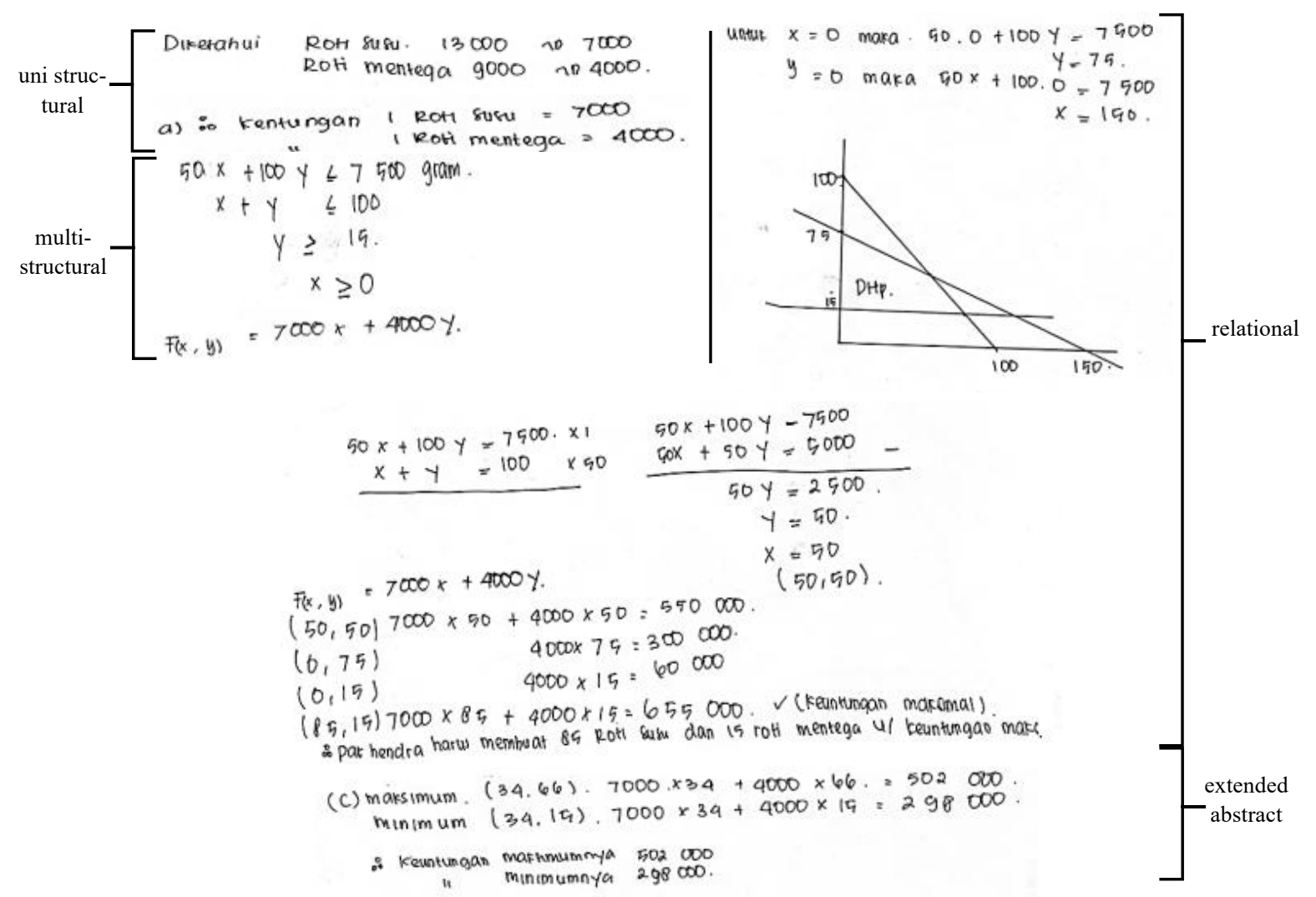

Figure 4. Answer of SM 1 to The Problem

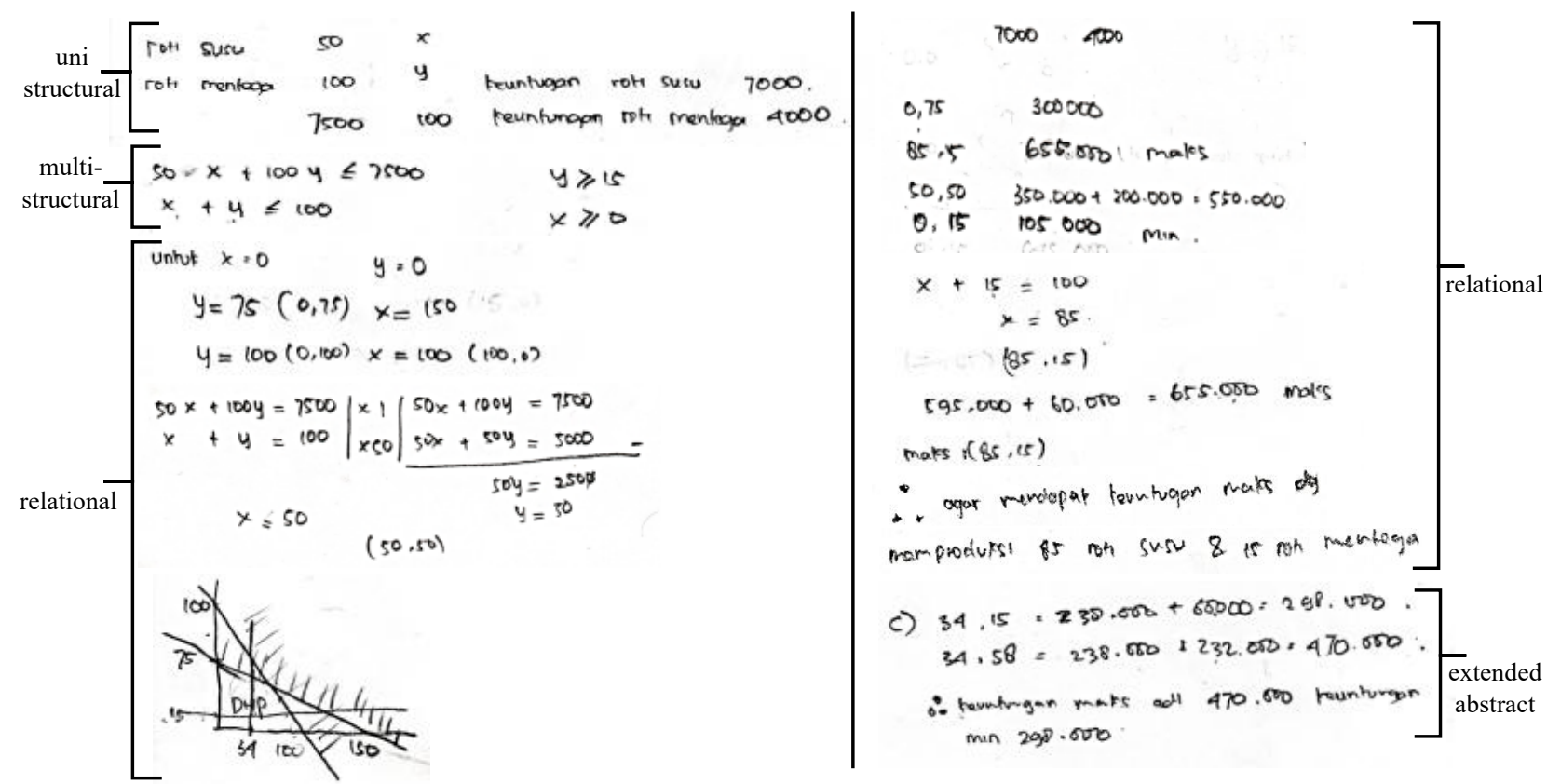

Figure 5. Answer of SM 2 to The Problem

Activities that indicate subject's response is at uni structural level are: (1) capturing and using a structure/information that is known from the problem to solve the problem, (2) solving the problem from the information provided directly, and (3) determining the profit from the sale of one milk bre- ad and one butter bread. This is corresponding with the uni structural level response scheme by Biggs \& Collis (1982) which is explained in more detail in Chick (1998) stating that students reach uni structural level if students can apply a single process or concept to at least one data or information item 
to solve a problem. In line with this, Lucas and Mladenovic (2009) stated that students at the uni structural level use information in the problem to solve the problem.

Activities that indicate that the subject's response is at the multi-structural level are: (1) capturing and using two or more structures/information from the problem to solve the problem given, (2) solving the problem by first completing information that is not yet known, namely information about the profits of the sale of one milk bread and one butter bread, (3) using information of the profits from the sale of one milk bread and one butter bread that has been obtained to determine the objective function, and (4) determining a mathematical model of the problem given. This is corresponding with the multi-structural level response scheme by Biggs \& Collis (1982) which is explained in more detail in Chick (1998) stating that students reach a multi-structural level if students can apply processes or concepts to more than one information structure contained in the problem to solve the problem.

Furthermore, activities that indicate subject's response is at the relational level are (1) connecting all relevant information, (2) using integrated strategies and concepts, (3) associating information from determined constraints to determine feasible set, and (4) determining the coordinates of the corner points and the optimum value of the given problem so that they can make relevant conclusions. This is corresponding with the relational level response scheme by Biggs \& Collis (1982) which is explained in more detail in Chick (1998) stating that students reach the relational level if students integrate all aspects of the information presented on the problem into related structures or related to each other. The information provided is not enough to solve the problem directly, but it needs additional information obtained through the implementation of concepts in some data. The additional information is related to other data or processes.

In working on point $\mathrm{c}$ of the problem, there are differences in answers by SM 1 and SM 2. SM 2 can answer the point $\mathrm{c}$ of the problem correctly as shown in Figure 4, while SM 1 gives the answer as shown in Figure 3 , but SM 1 still doubts about his answer as shown in interview passage below.

P : "How do you relate your results to other situations such as point c?"

SM 1 : "This is my prediction, Miss, but I am not sure."

P : : "Tell me how you got this answer!"

SM 1 : "34 milk breads means that the $x$ is equal to 34 . Then, the value of $n$ must be more than equal to 15 . Thus, the minimum profit at point $(34,15)$ is IDR 298,000 . Afterwards, most produce 100 breads, so 100 is reduced by 34 , the result is 66. Therefore, the maximum profit at point $(34,66)$ is IDR 502,000 . In calculating maximum benefit, I am still not sure and I am still confused, Miss. "

After being interviewed by the researcher, SM 1 realized the right steps to improve his answer. It was shown in interview passage below.

$\mathrm{P} \quad$ : "You said ${ }^{x}$ is equal to ${ }^{34}$, it means here (pointing to the $x_{\text {-axis), then }}$ what is the value of $n ? "$

SM 1 : "The value of $\mathrm{n}$ is more than 15 "

P $\quad$ : "So what are the possible ${ }^{n}$ values?"

SM 1 : "The values are many, Miss."

$\mathrm{P} \quad$ : "Can you explain the various possible values of ${ }^{n}$ on this graph?"

SM 1 : "Mmm ... Oh, I know, that means we can make a line, Miss. So, I have 
to find the intersection of the line $x=34 \quad$ with the line $50 x+100 y=7,500$. Hang on, Miss. I will count it first."

P : :Yes, please"

SM 1 : "I have found the answer, the maximum profit at point $(34,58)$ is IDR $470,000 "$

So that the final answers of point $\mathrm{c}$ by SM 1 and SM 2 are the same. Based on the two answers, the subject activity can be known which is a subject response form when faced with problems. Activities that indicate subject's response is at the extended abstract level are: (1) determining the maximum and minimum profit which obtained when successfully selling 34 milk breads and $n$ butter bread, and (2) making relevant conclusions and making generalizations to other situations or apply it to other situations. This is corresponding with the statement of Lian \& Idris (2006) that students at the extended abstract level can expand the application of information provided in new situations. In line with this statement, Lian \& Yew (2012) stated that students at the extended abstract level can apply all aspects of the data to other situations. Braband \& Dahl (2008) also provided a statement that students at this level can use their ideas in new situations.

The process of problem-solving by subjects with logical-mathematical intelligence tendency, when associated with the characteristics of students with logical mathematical intelligence tendencies, is shown by their ability in good mathematical calculations. Subjects with logical-mathematical intelligence tendency to solve the given problem using systematically arranged procedures.
This is corresponding with Afthina, et al. (2017) which stated that the superiority of students with logical-mathematical intelligence tendency is their ability to carry out the mathematical operation. Also, students with logical-mathematical intelligence tendencies have a high curiosity and continue to think about something that is considered wrong and not yet believed to be correct as shown by SM 1 when solving point $\mathrm{c}$ of the problem. This is in line with Yaumi (2012) which stated that the characteristics of students with logical-mathematical intelligence tendency is not stopping doing the task until all questions can be answered correctly by what he believes to be true.

Based on the discussion of the subjects' response activities with logical-mathematical intelligence tendency in solving linear programming problems as well as the relevant opinions of experts, it can be concluded that subjects with logical-mathematical intelligence tendency tend to respond at the uni structural, multi-structural, relational, and extended abstract levels. This is corresponding with the research conducted by Aoyama (2007) and Lian \& Idris (2006) which showed that high school students can reach the extended abstract level. Therefore, the response level of subjects with logicalmathematical intelligence tendency reached the extended abstract level.

\section{Students' Responses Leveling with Verbal Linguistic Intelligence Ten- dency}

Students with verbal-linguistic intelligence tendencies are labeled by SL 1 and SL 2. The answer of SL 1 is shown in Figure 6, and the answer of SL 2 is shown in Figure 7. 


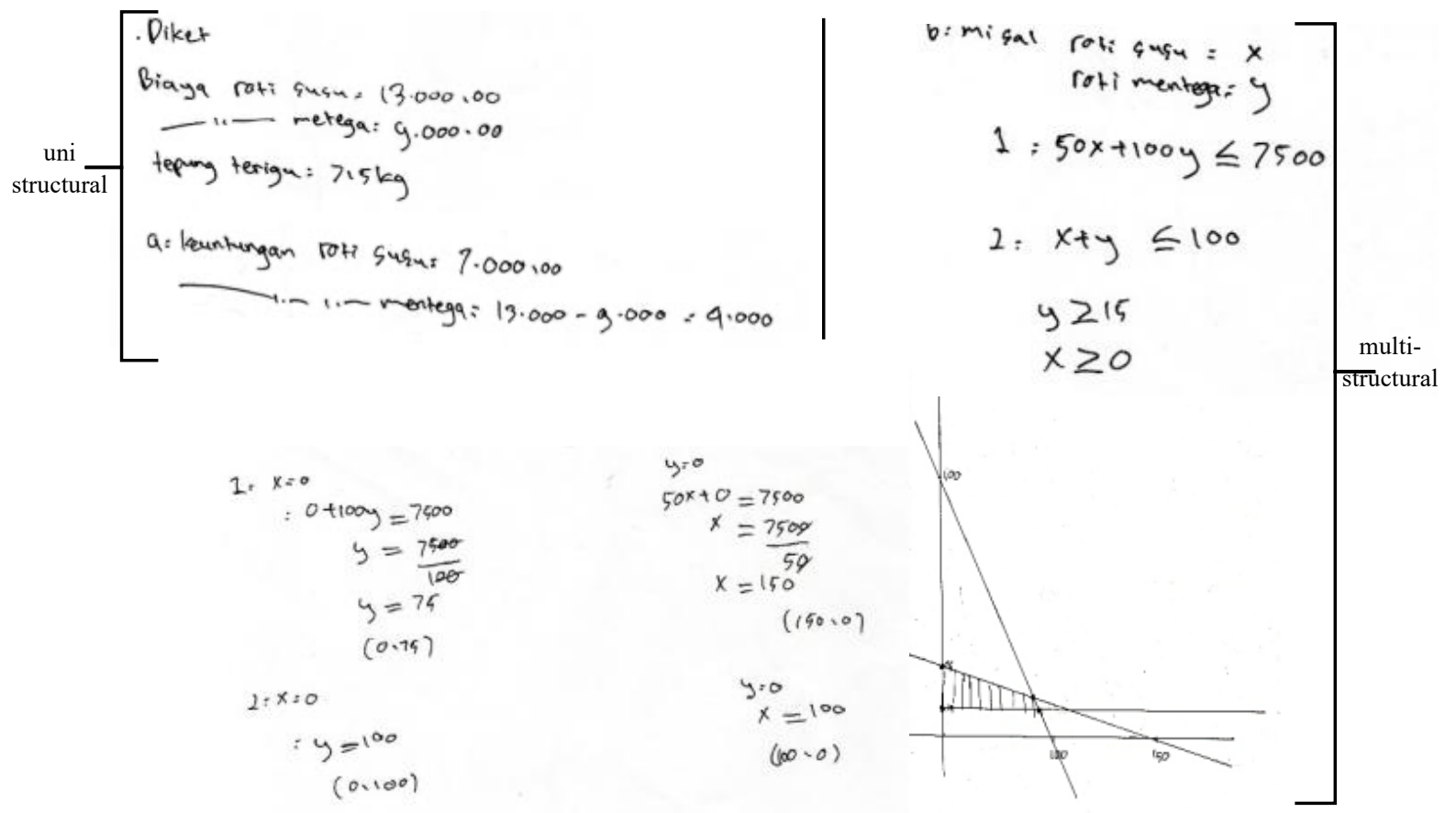

Figure 6. Answer of SL 1 to The Problem

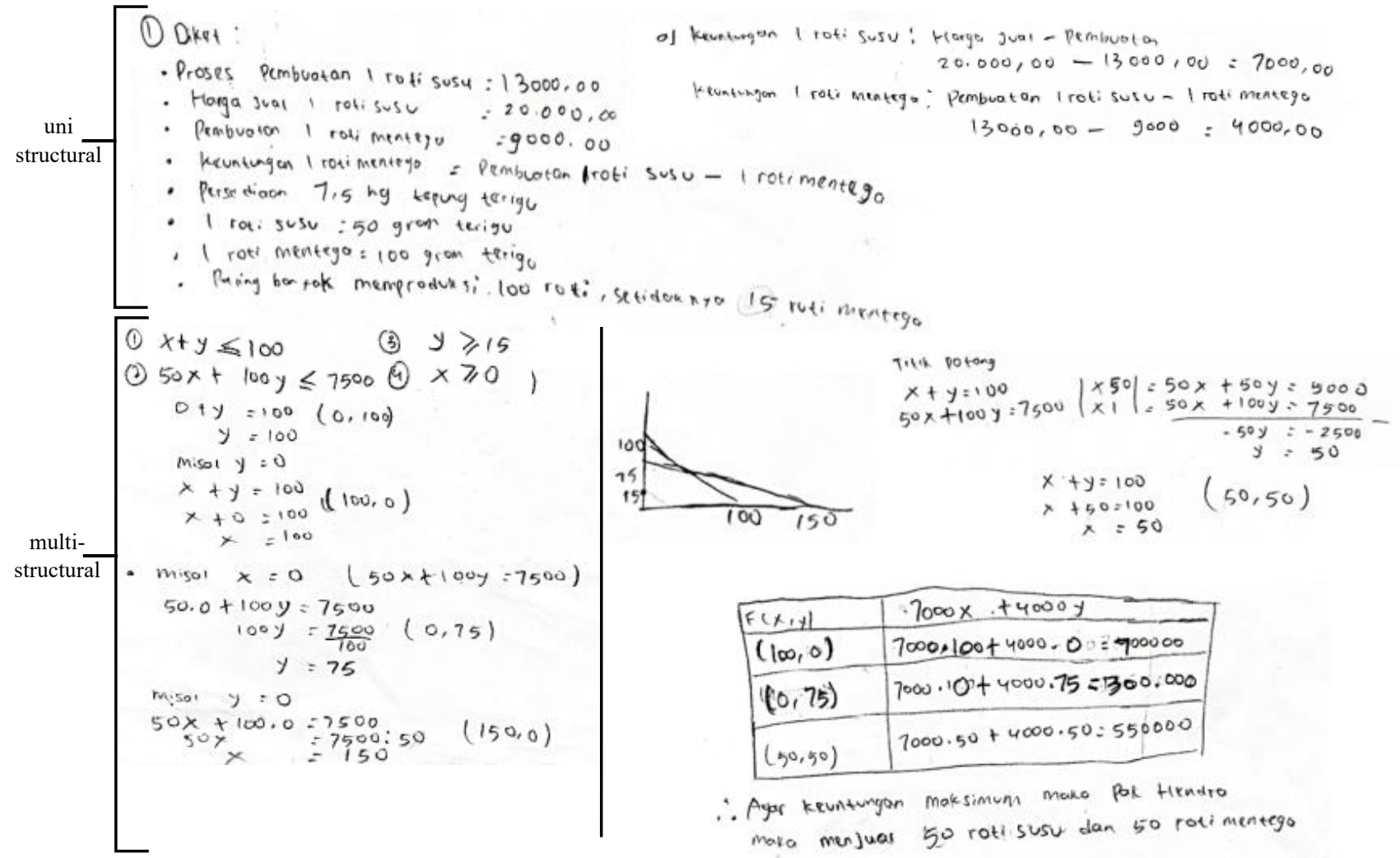

Figure 7. Answer of SL 2 to The Problem

Activities that indicate subject's respon- ning the profit from the sale of one milk brese is at uni structural level are: (1) capturing ad and one butter bread. This is in line with and using a structure/information that is the uni structural level response criteria proknown from the problem to solve the problem, (2) solving the problem from the information provided directly, and (3) determiposed by Putri et al. (2017) who stated that students on uni structural level response can be involved in one single aspect, make sim- 
ple algorithms, and make obvious connections.

Activities that indicate that the subject's response is at the multi-structural level are: (1) capturing and using two or more structures/information from the problem to solve the problem given, (2) solving the problem by first completing information that is not yet known, namely information about the profits of the sale of one milk bread and one butter bread, (3) using information of the profits from the sale of one milk bread and one butter bread that has been obtained to determine the objective function, and (4) determining a mathematical model of the problem given. This is in accordance with the multi-structural level response criteria by Sudihartinih (2019) who stated that students on multi-structural level response can solve the problem based on two or more information structures.

Based on answer sheet of SL 1 in Figure 6 and the results of the researcher's interviews with SL 1, it is known that SL 1 is not able to determine the coordinates of the corner points of the feasible set due to being unable to determine the coordinates of the intersection points of two lines. Consequently, SL 1 did not continue his calculations, so that SL 1 did not get a conclusion. While on the answer sheet of SL 2 in Figure 7 and the results of the interview with SL 2, it is known that SL 2 is not able to draw one of the inequalities as a constraint in the problem so that there are mistakes in the final results obtained. However, SL 2 continues to calculate, even though the conclusion she got was wrong because there was an error in processing. From this explanation, SL 1 and SL 2 made a mistake at the process skill stage. The process skill stage is the stage after students change the information in the problem into its mathematical form then the students do the calculation process, determi- ne the feasible set, and determine the optimum value or optimum point. According to Singh, et al (2010), mistakes in process skills occur when students can choose the methods needed to solve problems but are unable to carry out procedures correctly. For the point c of the problem, SL 1 and SL 2 do not give any answer. Whereas, the characteristic of students on relational level response can use a lot of data or information, do the process of finding additional information and connect data or other processes to make conclusions; and the charachteristic of students on extended abstract level response can generalize to other situations (Mulbar et al., 2017). Hence, based on the explanation of the location mistakes of SL 1 and SL 2 in solving linear programming problems, it indicates that the subjects' response has not yet reached the relational and extended abstract levels.

The process of problem-solving by subjects with verbal-linguistic intelligence tendency if related to the characteristics of students with verbal-linguistic intelligence tendency is shown by SL 2 which writes information about the problems he knows in detail. This is in line with Yaumi (2012) which stated that students with verballinguistic intelligence tendency can communicate their ideas both verbally and in writing well. Also, according to Sujarwo (2013), someone with verbal-linguistic intelligence tendency can use language to express what comes in mind, both verbally and in writing, as well as the ability to understand the words and writings of others. When SL 2 was interviewed by the researcher, students with verbal-linguistic intelligence tendencies showed a dislike to involve in mathematical problems. This is shown by his attitude which immediately gave up and did not want to think deeper when given a little help by the researcher. This attitude is corresponding with Gardner (2006) which stated that stu- 
dents with verbal-linguistic intelligence tendency prefer language lessons and have less interest in Mathematics.

Based on the discussion of the subject's response activities with verbal-linguistic intelligence tendency in solving linear programming problems as well as the relevant opinions of experts, it can be concluded that subjects with verbal-linguistic intelligence tendency tend to respond at uni structural and multi-structural levels. Therefore, the response level of subjects with verballinguistic intelligence tendency reaches a multi-structural level.

\section{Student Responses Leveling with Vi- sual-Spatial Intelligence Tendency}

Students with visual-spatial intelligence tendencies are labeled by SV 1 and SV 2. The answer of SV 1 is shown in Figure 8, and the answer of SM 2 is shown in Figure 9.

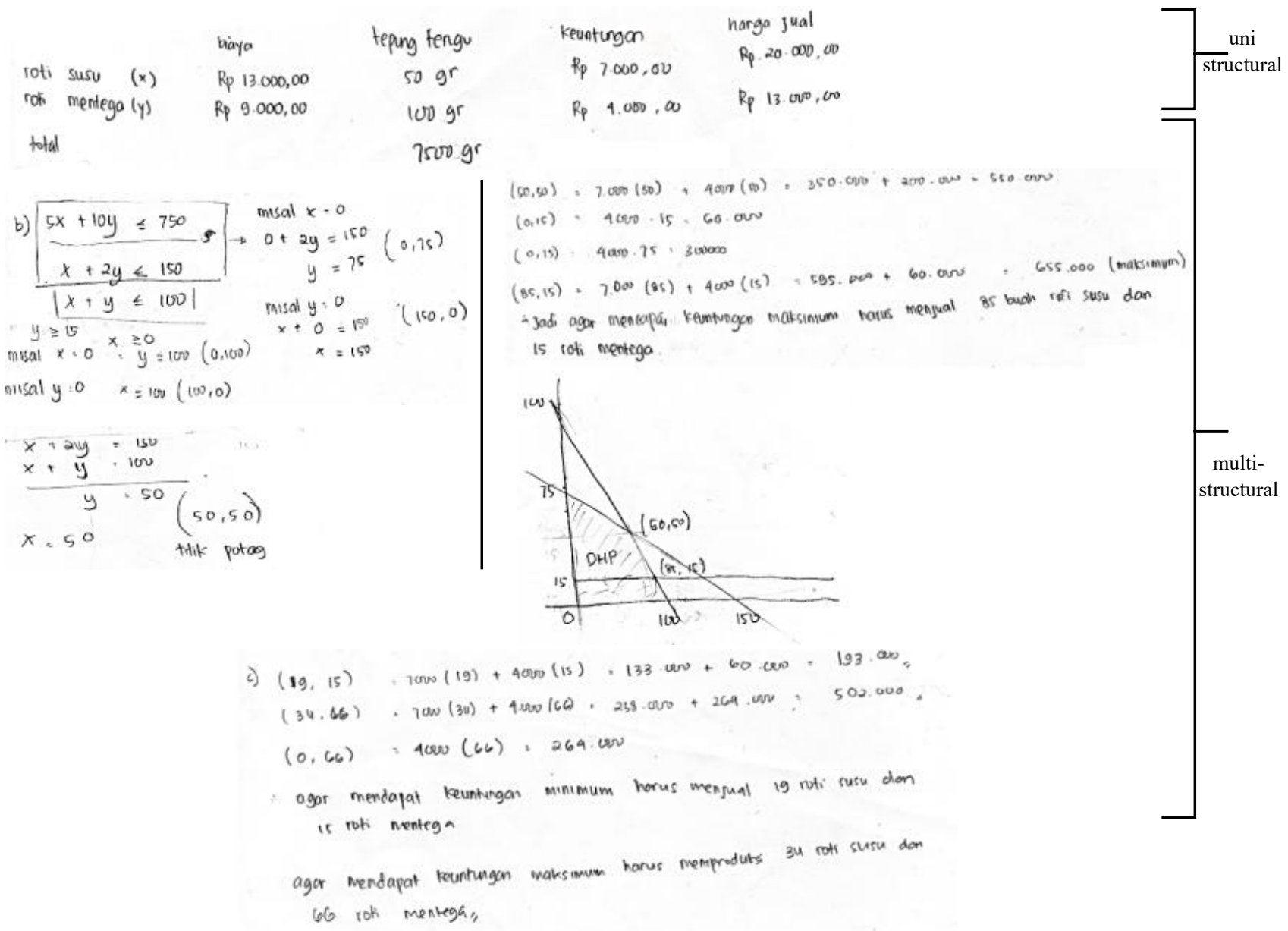

Figure 8. Answer of SV 1 to The Problem 


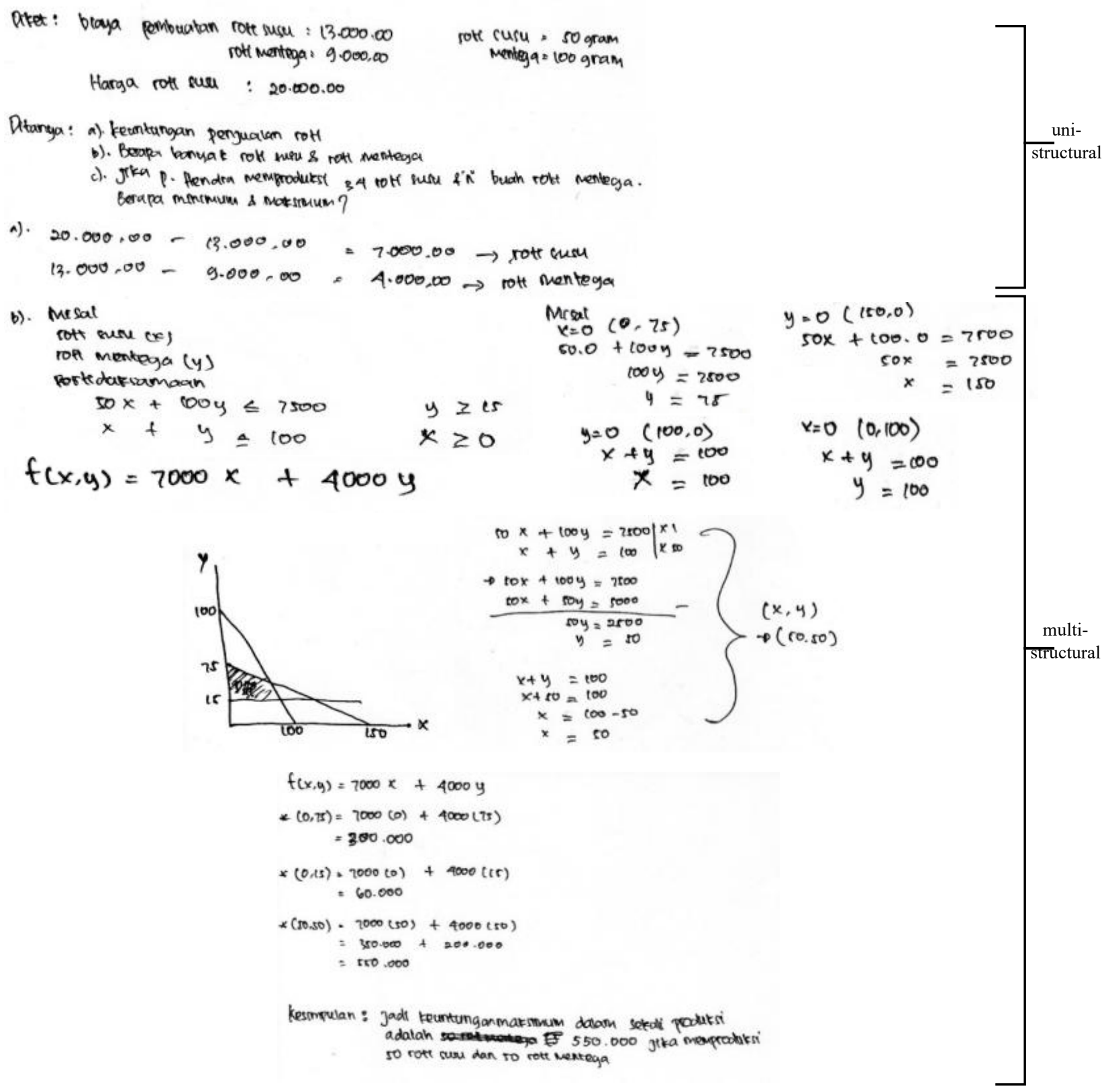

Figure 9. Answer of SV 2 to The Problem

Activities that indicate subject's response is at uni structural level are: (1) capturing and using a structure/information that is known from the problem to solve the problem, (2) solving the problem from the information provided directly, and (3) determining the profit from the sale of one milk bread and one butter bread. This is in accordance with the uni structural level response criteria by Biggs \& Tang (2011) who stated that students on uni structural level response only focus on using data related to questions.

Activities that indicate that the subject's response is at the multi-structural level are: (1) capturing and using two or more structures/information from the problem to solve the problem given, (2) solving the problem by first completing information that is not yet known, namely information about the profits of the sale of one milk bread and one butter bread, (3) using information of the profits from the sale of one milk bread and 
one butter bread that has been obtained to determine the objective function, and (4) determining a mathematical model of the problem given. This is in line with the multistructural level response criteria by Putri et al. (2017) who stated that students on multistructural level respons can be involved in several aspects that are considered unrelated, apply methods, and carry out procedures.

Based on the answer sheet of SV 1 and the interview with SV 1, it is known that SV 1 can determine the feasible set, as well as the optimum value and optimum point of the problem so that SV 1 can write the correct conclusion. Whereas in the SV 2 answer sheet in Figure 9 and the results of the researcher's interview with SV 2, it was found that SV 2 was unable to determine one of the corner point coordinates of the feasible set, so there was a mistake in the final results obtained. However, SV 2 continued to calculate. From the description, it is seen that SV 2 made a mistake at the process skill stage. According to Singh, et al (2010), mistakes in process skills occur when students can choose the methods needed to solve problems but are unable to carry out procedures correctly.

On the other hand, activities that indicate the response of SV 1 is at the relational level are (1) connecting all relevant information, (2) using integrated strategies and concepts, (3) associating information from determined constraints to determine feasible set, and (4) determining the coordinates of the corner points and the optimum value of the given problem so that they can make relevant conclusions. While the activities that indicate that SV 2 response has not reached the relational level are: (1) unable to connect all relevant information, (2) unable to use integrated strategies and concepts, and (3) unable to determine the coordinates of the corner points and the optimum value of the given problem so that she cannot make relevant conclusions. On the relational level response criteria by Putri et al. (2017), it is stated that students on relational level response can understand and explain the relation among several aspects, connecting, analyzing, and applying theories. This experts' opinion also indicates that the response SV 1 has reached the relational level, while the SV 2 response has not yet reached the relational level.

In working on point $\mathrm{c}$ of the problem, SV 1 answered, while SV 2 did not provide the answer. From the answer of SV 1 in Figure 7 and interview with SV 1, SV 1 answered with irrelevant steps, so that SV 1 got irrelevant conclusions. SV 1 also wrote conclusions that did not correspond with the questions in the problem (writing error on the final answer). According to Singh, et al. (2010), writing errors in the final answer occurs when students incorrectly write the conclusion of the answer even though they have finished solving the problem. Whereas, students on extended abstract level response can make generalization to other situation (Biggs \& Tang, 2011). Hence, by the explanation above, the mistake of SV 1 and SV 2 indicates that the response of the two subjects has not reached the extended abstract level.

The process of problem-solving by subjects with visual-spatial intelligence tendency if related to the characteristics of students with visual-spatial intelligence tendencies that are indicated by SV 1 prefers to presented information from the problem by using a table to make it easier to solve the problem. This is in line with Yaumi (2012) which stated that students with visual-spatial intelligence tendency tend to like to present data in the form of graphics, diagrams, or tables. Also, SV 2 can draw graphs according to the information in the problem, but SV 2 cannot 
determine the corner points of the feasible set by algebra. This is in line with Gardner (2006) stating that students with visualspatial intelligence tendency feel that the concept of geometry is easier than the concept of algebra.

Based on the discussion of the subjects' response activities with visual-spatial intelligence tendency in solving linear programming problems and the relevant opinions of experts, it can be concluded that subject SV 1 tends response at uni structural, multistructural, and relational levels. While SV 2 subject tends responses at the uni structural and multi-structural levels. Therefore, the response level of subjects with visual-spatial intelligence tendency reaches the relational and multi-structural levels.

\section{Conclusion}

Based on the results of research and discussion, it can be concluded that the response levels of students of Grade XI of Natural Science 1 Department at SMAN 1 Gondanglegi are (1) students with logicalmathematical intelligence tendency in solving linear programming problems are at the extended abstract level, (2) students with verbal-linguistic intelligence in solving linear programming problems are at the multistructural level, and (3) students with visualspatial intelligence tendency in solving linear programming problems are at the relational and multi-structural levels.

\section{References}

Afthina, H., \& Pramudya, I. (2017). The Comparison of Think Talk Write and Think Pair Share Model with Realistic Mathematics Education Approach Viewed from Mathematical-Logical Intelligence. International Journal of Science and Applied Science: Conference Series, 2(1), 181-189. https://doi.org/10.20961/ijsascs.v2i1. 16706
Allan, B. A., \& Shearer, B. (2012). The Scale for Existential Thinking. International Journal of Transpersonal Studies, 31(1), 21-37. https://doi.org/10.24972/ijts.2012.31. 1.21

Aoyama, K. (2007). Investigating a Hierarchy of Student's Interpretations of Graphs. International Electronic Journal of Mathematics Education, 2(3), 298-318.

Bhat, M. A. (2014). Effect of Problem Solving Ability on the Achievement in Mathematics of High School Students. Indian Journal of Applied Research, 4(8), 685-688. https://doi.org/10.15373/2249555X/A ugust2014/195

Biggs, J. B., \& Collis, K. F. (1982). Evaluating the Quality of Learning: The SOLO Taxonomy (Structure of The Observed Learning Outcome). Academic Press.

Biggs, J. B., \& Tang, C. (2011). Teaching For Quality Learning at University Thrid es. McGraw-Hill and Open University Press.

Brabrand, C., \& Dahl, B. (2008). Constructive Alignment and the SOLO Taxonomy: A Comparative Study of University Competences in Computer Science vs. Mathematics. Conference in Research and Practice in Information Technology, Aalborg University, Denmark.

Chick, H. (1998). Cognition in the formal modes: Research mathematics and the SOLO taxonomy. Mathematics Education Research Journal, 10(2), 4-26.

https://doi.org/10.1007/BF03217340

Duncker, K. (1945). On problem-solving. (L. S. Lees, Trans.). Psychological Monographs, 58(5), i-113. https://doi.org/10.1037/h0093599

Ekawati, R., Junaedi, I., \& Nugroho, S. E. (2013). Studi Respon Siswa dalam Menyelesaikan Soal Pemecahan Masalah Matematika Berdasarkan Taksonomi SOLO. Unnes Journal of Ma- 
thematics Education Research, 2(2), 101-107.

Gardner, H. (1999). Intelligence Reframed: Multiple Intelligences for The 21st Century. Basic Books.

Gardner, H. (2006). Multiple Intelligences. Basic Books.

Gardner, H. (2011). Frames of Mind the Theory of Multiple Intelligences. Basic Books.

Hasan, B. (2017). Karakteristik Respon Siswa Dalam Menyelesaikan Soal Geometri Berdasarkan Taksonomi SOLO. JINoP (Jurnal Inovasi Pembelajaran), 3(1), 449-458. https://doi.org/10.22219/jinop.v3i1.4 282

Ilyas, S. N. (2019). Aplikasi Multiple Intelligences System (MIS) dalam Pembelajaran Anak Usia Dini Studi Kasus di Rumah Sekolah Cendekia Makassar. PAUDIA : Jurnal Penelitian dalam Bidang Pendidikan Anak Usia Dini, 8(2), 50-56. https://doi.org/10.26877/paudia.v8i2. 4882

Kuswana, W. S. (2014). Taksonomi Kognitif. PT. Remaja Rosdakarya.

Lian, L. H., \& Idris, N. (2006). Assessing Algebraic Solving Ability of From Four Students. International Electronic Journal of Mathematics Education, 1(1), 55-76.

Lian, L. H., \& Yew, W. T. (2012). Assessing Algebraic Solving Ability: A Theoretical Framework. International Education Studies, 5(6), 177-188. https://doi.org/10.5539/ies.v5n6p177

Lucas, U., \& Mladenovic, R. (2009). The identification of variation in students' understandings of disciplinary concepts: The application of the SOLO taxonomy within introductory accounting. Journal for Higher Education, 58(2), 257-283. https://doi.org/10.1007/s10734-0099218-9

Miles, M. B., Huberman, A. M., \& Saldaña, J. (2014). Qualitative data analysis:
$A$ methods sourcebook (Third edition). SAGE Publications, Inc.

Mishra, S. K., \& Ram, B. (2018). Introduction to linear programming with MA$T L A B$. Taylor \& Francis, CRC Press.

Mulbar, U., Rahman, A., \& Ahmar, A. S. (2017). Analysis Of The Ability In Mathematical Problem-solving Based on SOLO Taxonomy and Cognitive Style. World Transactions on Engineering and Technology Education, 15(1), 68-73. https://doi.org/10.26858/wtetev15i1y $2017 \mathrm{p} 6873$

Novitasari, D. (2016). Pengaruh Penggunaan Multimedia Ineteraktif Terhadap Kemampuan Pemahaman Konsep Matematis Siswa. FIBONACCI: Jurnal Pendidikan Matematika dan Matematika, 2(2), 8-18. https://doi.org/10.24853/fbc.2.2.8-18

Nugroho, R. A., Sutinah, \& Setianingsih, R. (2013). Proses Berpikir Siswa dengan Kecerdasan Linguistik dan Logis Matematis dalam Memecahkan Masalah Matematika. MATHEdunesa Jurnal Ilmiah Pendidikan Matematika, 2(3), 8.

Putri, U. H., Mardiyana, M., \& Saputro, D. R. S. (2017). How to Analyze the Students' Thinking Levels Based on SOLO Taxonomy?. Journal of Physics: Conference Series, 895. https://doi.org/10.1088/17426596/895/1/012031

Rahbarnia, F., Hamedian, S., \& Radmehr, F. (2014). A Study On The Relationship Between Multiple Intelligences and Mathematical Problem Solving Based on Revised Bloom Taxonomy. Journal of Interdisciplinary Mathematics, 17(2), 109-134. https://doi.org/10.1080/09720502.201 3.842044

Salistiyani, Usodo, B., \& Pramudya, I. (2016). Respon Siswa Dalam Memecahkan Masalah Matematika Pada Materi Geometri Berdasarkan Taksonomi SOLO Ditinjau Dari Tingkat Metakognisi Siswa Kelas X SMA 
Negeri 1 Cepu. Jurnal Elektronik Pembelajaran Matematika, 4(9), 802-811.

Singh, P., Rahman, A. A., \& Hoon, T. S. (2010). The Newman Procedure for Analyzing Primary Four Pupils Errors on Written Mathematical Tasks: A Malaysian Perspective. Procedia Social and Behavioral Sciences, 8, 264-271.

https://doi.org/10.1016/j.sbspro.2010. 12.036

Sudihartinih, E. (2019). Facilitating Mathematical Understanding In ThreeDimensional Geometry Using The SOLO Taxonomy. Erudio Journal of Educational Innovation, 6(1), 11-18. https://doi.org/10.18551/erudio.6-1.2

Sugiarto, E. C. (2019). Pembangunan Sumber Daya Manusia (SDM) Menuju Indonesia Unggul. https://www.setneg.go.id/baca/index/ pembangunan_sumber_daya_manusia sdm_menuju_indonesia_unggul

Sujarwo, A. (2013). Proses Berpikir Siswa SMK dengan Kecerdasan Linguistik, Logika Matematika, dan Visual Spasial dalam Memecahkan Masalah Matematika. E-Jurnal Dinas Pendidikan Kota Surabaya, 3, 1-13.
Sulaiman, T., Abdurahman, A. R., \& Rahim, S. S. A. (2010). Teaching Strategies Based on Multiple Intelligences Theory among Science and Mathematics Secondary School Teachers. Procedia - Social and Behavioral Sciences, 8 , 512-518. https://doi.org/10.1016/j.sbspro.2010. 12.070

Wardani, N. K., Sutopo, \& Pambudi, D. (2017). Profil Respons Siswa Berdasarkan Taksonomi SOLO dalam Memecahkan Masalah Matematika Pada Materi Pokok Lingkaran Ditinjau dari Adversity Quotient. Jurnal Pendidikan Matemtika dan Matematika (JPMM), 1(4), 91-107.

Yaumi, M. (2012). Pembelajaran Berbasis Multiple Intelligences. PT. Dian Rakyat.

Zulfairanatama, G., \& Hadi, S. (2013). Kecerdasan Logika-Matematika Berdasarkan Multiple Intelligences terhadap Kemampuan Matematika Siswa SMP di Banjarmasin. EDU-MAT: Jurnal Pendidikan Matematika, 1(1), 18-26. https://doi.org/10.20527/edumat.v1i1. 549 